\title{
地震観測に基づく不整形地盤による 上下動増幅要因の検討
}

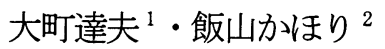 \\ '正会員 工博 東京工業大学教授 大学院総合理工学研究科 （广226-8502 横浜市緑区長津田町 4259） \\ ${ }^{2}$ 正会員 工修 中央復建コンサルタンツ(株) (研究当時 同上 修士課程)
}

\begin{abstract}
鎌倉市街地の 6 地点で地震観測を続けた結果，西御門(NMD) と御成(ONR)の 2 地点は系統的に顕著な上 下動を示すことが判明した. NMD地点では上下動と水平動の最大加速度比は平均的に 0.75 で 1 を越える時も あり，皒越期は上下，水平ともに $0.2 \sim 0.3 \mathrm{sec}$ でほぼ一定している. 一方, ONR地点では最大加速度比の 平均は 0.70 で, 卓越周期は上下動は $0.21 \sim 0.26 \mathrm{sec}$ でほぼ一定しているが, 水平動は $0.1 \sim 0.6$ 秒で変動する 傾向が強い，2地点における上下動堌幅の要因を解明するため，2次元境界要素法による数值解析を行った．そ の結果，両地点ともに急傾斜基盤の影響が強いと考えられるものの，前者には椀形表層地盤の基本振動モード が，後者には片側開放地艋における Rayleigh 波が関与している可能性が高いことが指摘された.
\end{abstract}

Key Words: earthquake observation, vertical ground motion, irregular ground, 2-D BEM

\section{1. まえがき}

地表で強震観測を行うと，上下動は水平動よりも振幅 が小さく, 最大加速度値にしても前者は後者の $1 / 2 \sim 1 / 3$ 程度を示すことが多い1)。従来，わが国の耐震設計で 地上構造物に対する地震力としては, 主として水平力が 重視され，上下 (鉛直) 力は無視されるか，あるいは考 慮される場合にも水平力の $1 / 2$ 程度を考慮すればよいと されてきた ${ }^{2)}$ のは，このような事情にもよるのであろ うと推察される. しかし一方で, 多数の強震記録を統計

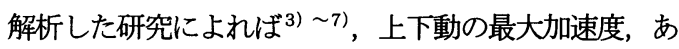
るいはそれと水平動の最大加速度との比（以下，上下 ・ 水平最大加速度比, または単に最大加速度比と略称す る）は，地震のマグニチュードM や観測点と震源（また は震源断層）との距離 $\mathrm{R}$ に依存することが指摘され，M やRを変数とする距離减衰式が幾つか提案されている. これらによれば, Mが大きく Rが小さいとき，すなわち 大地震の震源近傍では, 最大加速度比は 1 に近づき, と きには1を越えることが推測される.
実際，上下・水平最大加速度比が 1 を上回った事例は, 震源近傍で観測された強大地震動の観測記録に比較的多 く見られる. たとえば, 文献8）の付表 3からは, 1976 年のガズリ地震 (M7.0) においてカラキル地点で水平 $0.75 \mathrm{G}$ (Gは重力加速度), 上下 $1.33 \mathrm{G}$ が観測された事例 をはじめ8例が見いだせるが，これらのうち7例はRが $9 \mathrm{~km}$ 以下の事例である. また, 8例中の 2 例は, 液状 化に伴って周辺地盤のせん断岡性が大幅に低減したこと による特例9) と考えられる.

近年, 1994 年ノースリッジ地震や 1995 年兵庫県南部 地震などの都市直下地震が相次いで発生し, 甚大な被害 をもたらした. これらの地震後に行われた被害原因の究 明過程において, 直下地震による強い衝撃的な上下動を 伴う地震動が深刻な被害を発生させた要因ではないかと いう見解が多く発表された ${ }^{10)}$ 。 しかし震源域での強震 記録は，上述の液状化に関連する特例を除けば，いずれ も水平動が上下動を上回る強さを示し, 特に顕著な衝撃 的上下動は認められなかった. このため, これらの見解 は未だに単なる憶測の域を出ていない! また, 観測記録 によれば, 上下・水平最大加速度比は遠地地震よりも近 
地地震で大きな值を示寸傾向があるものの, 震源域で全 般的に上下動が水平動に匹敵するというわけではなく, 最大加速度比が 1 を越えるのはむしろ例外的と言える状 況である.さらに震原近傍での上下動と水平動の強さの 割合は, 震源断層が正断層, 逆断層, 横ずれ断層のいず れの型であるかにも依存するという指摘もある ${ }^{11)}$ が, 定説となるまでには至っていない.

以上のように, 地震動の上下動成分が水平動成分と匹 敵する強さを示す要因として, 震源特性や距離减衰特性, あるいは液状化地盤や不整形地盤 ${ }^{22)}$ の震動特性などが 指摘されてきたが, 地震観測に基づく系統的な解明は遅 れている. 昨今, 而震設計の高度化や合理化のための努 力が各方面で行われているが，上下動の効果を適切に評 価することもその重要項目の一つとされている ${ }^{13)}$. そ のためには，どのような物理的条件が強い上下動をもた らすかを実証的に解明する必要性が高い。

著者らは，約 3 年前から鎌倉市街地において地震観測 をおこなってきた. その結果, 現在までに $5 \mathrm{~cm} / \mathrm{s}^{2}$ 以上 の最大加速度を示す記録が 250 波形以上得られている. これらの記録を概観すると，震源や観測点の相違により 地震動はかなり異なるが, 特定の地点では比較的大きな 上下動が系統的に観測される傾向が認められる. 本論文 ではこの点に着目し，そのような上下動が観測される要 因を不整形地盤の震動特性の観点から検討する.

\section{2. 鎌倉の地形と地震観測点}

鎌倉市街地と周辺の地形及び地震観測点の位置を図-1 に示寸. 鎌倉市街地は雪の下 (YKS) 付近を頂点に由 比ヶ浜（YU I ） 一と広がる平坦な低地にあり，これを 海抜 $100 \mathrm{~m}$ 前後の丘陵が取り囲んでいる. 北東から南人 進路を変えて流下寸る滑川は, 河口に近づくほど土砂を 厚く堆積させている. その表層の堆積厚さは，鎌倉市街 地において行われている多数のボーリング調査結果 ${ }^{14)}$ 炕よれば，由比ヶ浜付近で約 $25 \mathrm{~m}$ である.

図-1 に示寸 6 地点のうち, ONR (御成) は科学技 術庁のK-net 地点 (KNG005) であり, 地震計は鎌倉市役 所敷地内の地表に設置されている. これ以外の 5 地点の 地震計は，いずれも建物内 1 階に設置されている. その ため厳密には，地震記録に建物振動の影響が含まれてい る可能性があるが, 微動実測によって検討した限りでは, 建物の影響は小さく無視できる.これら6地点の中で上 下動の加速度が比較的大きい地点は, 後述のようにNM $\mathrm{D}$ (西御門) とONRである.

なお，地震観測地点のうちONRでは，標準貫入試験 のN值や弾性波速度が得られているので，これらを図-2 に示寸.

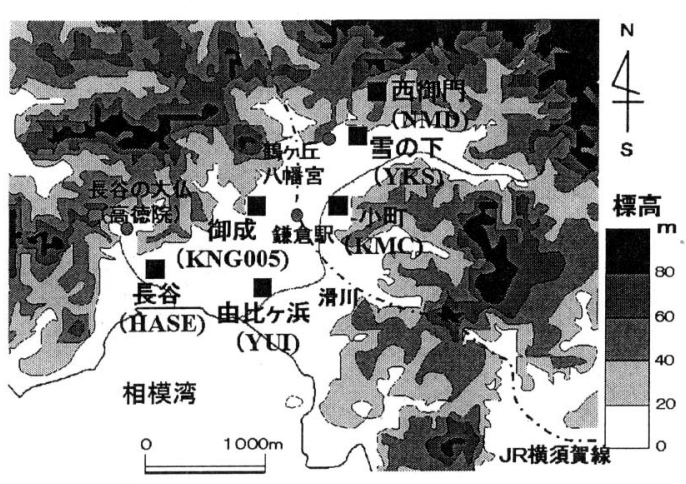

図-1鎌倉市街地の地形及び地震観測点

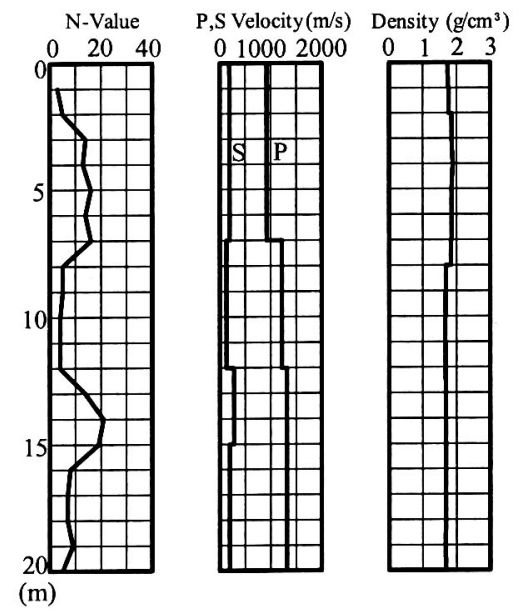

図-2 N值, 弾性波速度及ひ密度分布(ONR地点 $)^{15)}$

\section{3. 観測記録に見られる地震動の特性}

\section{(1) 観測記録の例}

現在までに観測された 52 地震, 450 成分の記録のう ちで最大の水平加速度值は $46 \mathrm{~cm} / \mathrm{s}^{2}$ である. また最大 加速度が $5 \mathrm{~cm} / \mathrm{s}^{2}$ を超える記録は 31 地震, うち上下動 の最大加速度が $5 \mathrm{~cm} / \mathrm{s}^{2}$ を超える記録は 13 地震である.

観測された加速度記録の例を図-3 に，地震のマグニ チュードや震央位置などとともに示す． 2 つ地震は震 源の位置が異なる. また, 各地点ごとの時刻は厳密には 同期していない. 上下動を示す図-3下段に着目すると，

NMDとONRにおいて上下動振幅が比較的大きいとい う特徵が共通して認められる. この 2 地点では水平動振 幅も比較的大きいので, 次の (2)では上下動と水平動の 振幅比に注目する. なお，これらの 2 つの地震を含め, 観測された地震の震源距離Rはいずれも $\mathrm{R}>50 \mathrm{~km}$ であ る. 

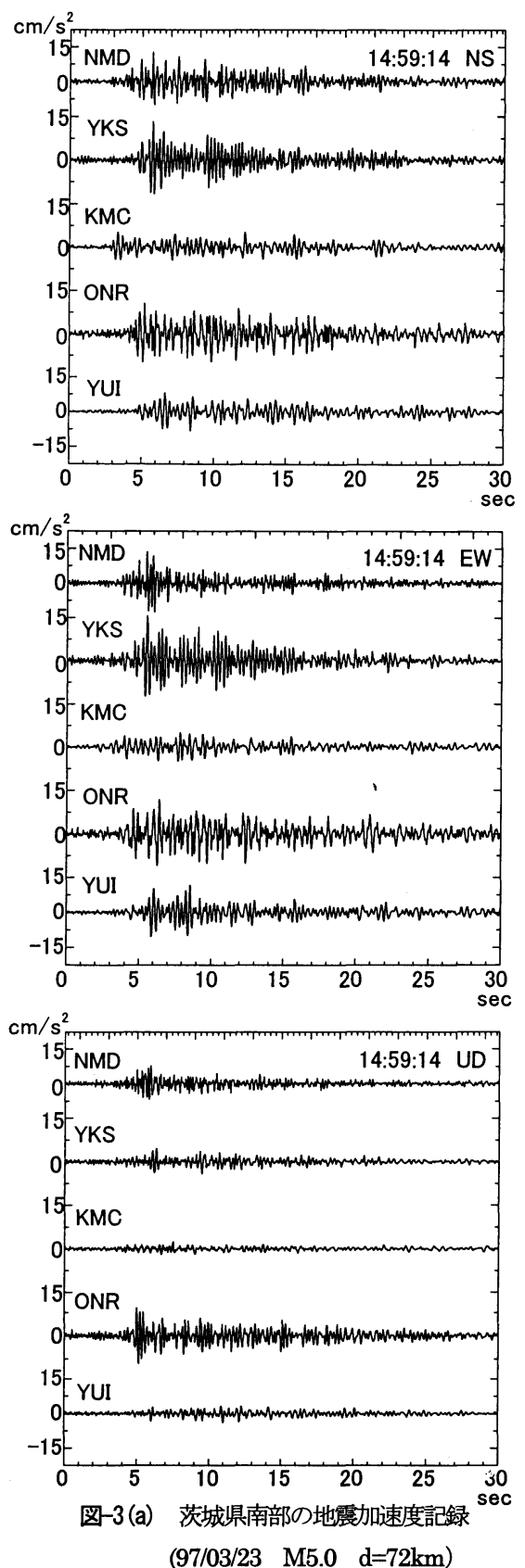

$(97 / 03 / 23$ M5.0 $\mathrm{d}=72 \mathrm{~km})$
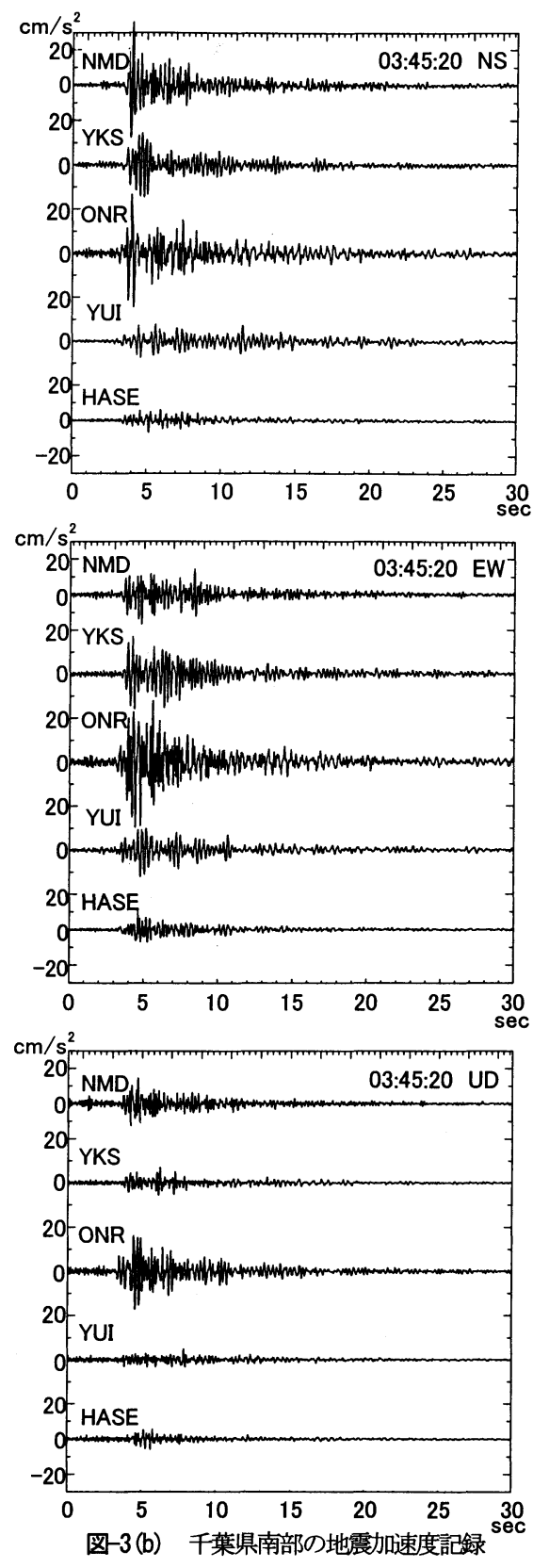

$(98 / 05 / 16$ M4.9 $\mathrm{d}=70 \mathrm{~km})$

\section{（2）最大加速度比に見られる特性}

各地点の上下動と水平動の強さの関係を表す簡単な 指標として，上下成分と水平成分の最大加速度比，すな わち

$$
\mathrm{q}=\mathrm{AV} / \mathrm{AH}
$$

をとり，プロットすると図-4 のようになる. NMDや ONRの 2 地点では, 微小地震時にも比較的大きな上下 動が観測される傾向があるが，図-4 は上下動の最大加
速度が $5 \mathrm{~cm} / \mathrm{s}^{2}$ を超える観測記録を用いた場合の結果で ある. 最大加速度比 q は変動幅が大きいが, $\mathrm{q}$ の平均值 $\mathrm{q}^{*}$ に着目すると，他の 4 地点では $\mathrm{q}^{*}<0.5$ であるのに 対し，NMDとONRの 2地点では $\mathrm{q}^{*}$ はそれぞれ 0.75, 0.70 であり，これらの地点では平均的に上下動は水平 動の 7 割以上の最大加速度を示すことが注目される. 特 にNMDでは， q>1 の場合もあることが，注目される. 


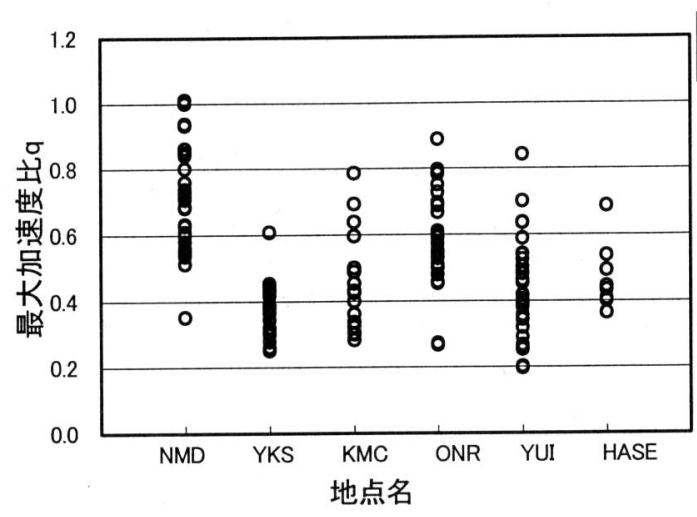

図-4 上下動と水平動の最大加速度比 $\mathrm{q}$

観測した地震の震央は, 福島県, 茨城県, 千葉県, 埼 玉県, 山梨県, 愛知県, 房総半島沖, 伊豆半島沖などに 位置している. 観測点に対する震央の方位と最大加速度 比 $\mathrm{q}$ との関係を，NMD地点での全観測記録に関して示 すと図-5のようになる. 図中の同心円に付した0.0〜1.2 の数字は，qの值を示す. 伊豆半島東方沖や千葉県北西 部の地震で $\mathrm{q}>1$ が観測されているが, 同じ方位の地震 で $\mathrm{q}<0.6$ となる場合もあり，震央方向や震源位置と最 大加速度比 q との間に明瞭な関係は認められない.

\section{（4）最大加速度と卓越周期との関係}

観測記録の最大加速度と周期特性との関連性を調べる ために, 各加速度時刻歴のフーリエスペクトルを求め, そのピーク周期と最大加速度值との関係をプロットした のが図-6 である. 図-6 によれば，NMDでは上下動と 水平動の卓越周期がそれぞれ，0.20 sec 前後と 0.2 $0.3 \mathrm{sec}$ でほぼ一定している. ONRでは上下動の周期 は0.21〜0.26sec の狭い帯域にまとまっているが, 水平 動の周期は $0.1 〜 0.6 \mathrm{sec}$ と比較的広い带域に分散してい る. 一方, YKSでは水平動の周期は $0.25 \mathrm{sec}$ 前後でほ ぼ一定しているが, 上下動の周期は 0.1〜0.6sec で変動 する. またKMCやYU I では，水平動も上下動も卓越 周期が一定しない.

このようにNMDとONRでは，上下動の加速度が比 較的大きく，その卓越周期がそれぞれほぼ一定している という共通点があるが，水平動の卓越周期はNMDでは ほぼ一定であるが，ONRでは一定しないという相違点 がある.

\section{（5）鉛直面内における粒子軌跡の特徵}

NMD，YKS，ONRおよびYUIの4地点にお いて観測された加速度時刻歷が，NS（南北）と EW（東 西）の $2 つ の$ 鈶直平面内で描く粒子軌跡（オービット）

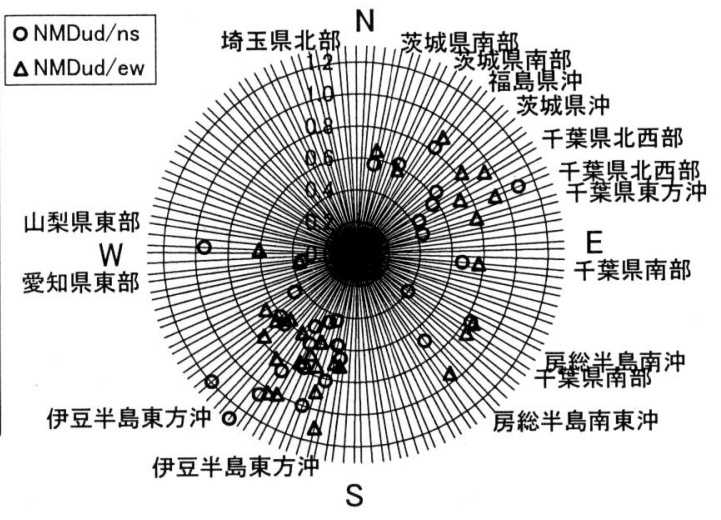

図-5 最大加速度比 $\mathrm{q}$ と震央方位の関倸(NMD 地点)

をそれぞれ図-7に示す．これらの図は図-3(a) と対応し， その 3 8sec の 5 秒間の粒子軌跡である. 図-7 に示す 加速度軌跡に関しては，YKSとYU I の地点で扁平な 水平軌跡が卓越している一方，NMDやONRの地点で は傾斜した棈円状ないし直線状の軌跡が多く見られる.

粒子軌跡の特徵は，観測した地震ごとにいくらか異な り，全ての観測記録に上述の特徴が常に共通して認めら れるわけではない，しかし本研究で対象としている，上 下動加速度が比較的大きい観測記録の場合, その観測点 では鉛直面内の加速度軌跡は楕円形状を示寸傾向が強く， 他地点でその傾向は見られない，よって，この大きな上 下動の生成には当該観測地点の地盤震動特性が関与して いる可能性が高いと推察される.

\section{4. 数值解析による検討}

観測記録に認められた上述の特性が，不整形地盤のど のような震動特性に起因するのかを数值解析によって検 討する. 本来は， 3 次元モデルによって各地点の震動特 性を抽出することが望ましいが，ここでは第一段階とし てNMDとONRの 2 地点を対象に 2 次元境界要素法に よる線形解析を行った.

\section{（1）地盤モデルと入射波}

地震観測地点周辺の詳細な地盤条件は明かでないが, NMD地点周辺では直径 $60 \mathrm{~m}$ 程度の狭い表層を椀形の基 盤が囲んでいる. ONR地点周辺の基盤は北に向かって $1 / 5$ 程度の勾配で傾斜するとともに西方約 $200 \mathrm{~m}$ にかけ て $2 / 3$ 程度の勾配で傾斜しているが，南方と東方に向け てはほぼ平坦と考えられる。

解析に用いた地盤モデルを図-8，9に示寸．図示のよ うに両地点ともに 2 層地盤とし，表-1 に示寸物性值を 与えた. ONR地点表層の物性值はPS 検層データ（図一 


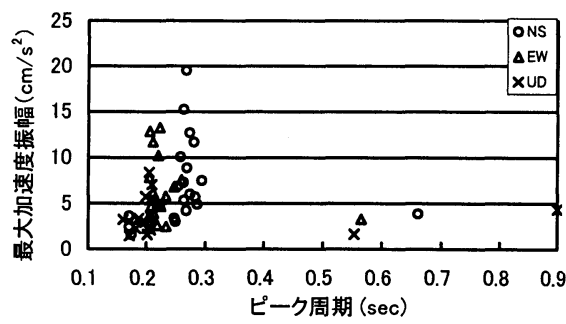

(a) NMD

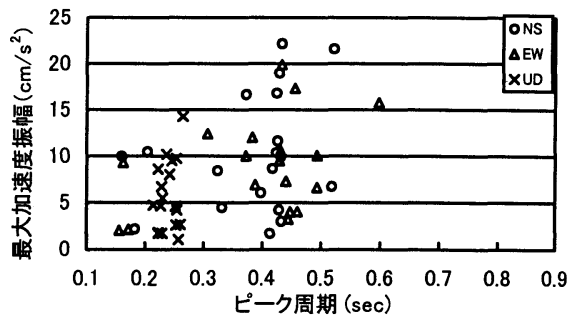

(c) ONR

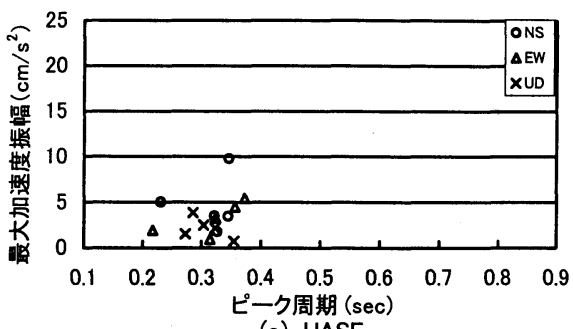

(e) HASE

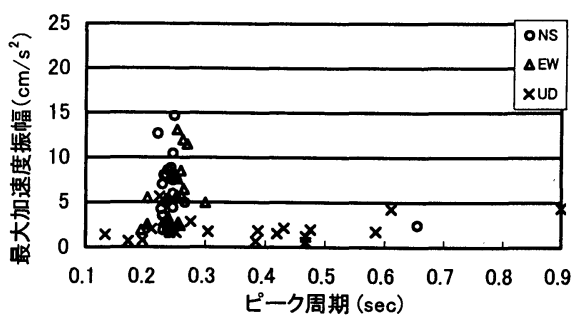

(b) YKS

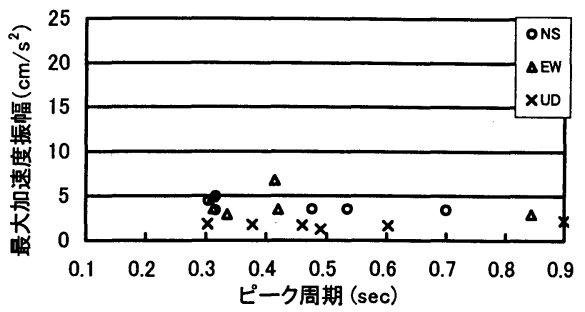

(d) KMC

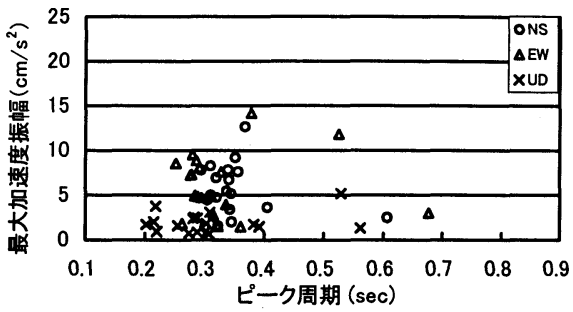

(f) YUI

図-6 最大加速度值と卓越周期
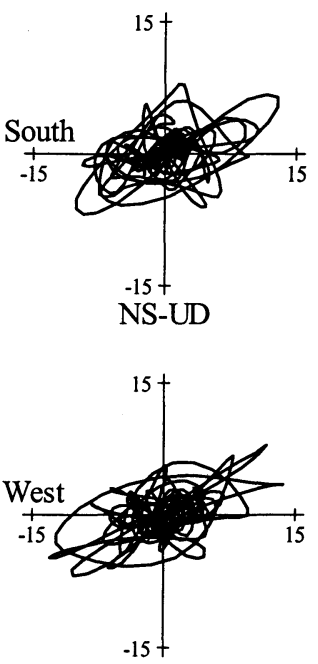

EW-UD

(a) NMD
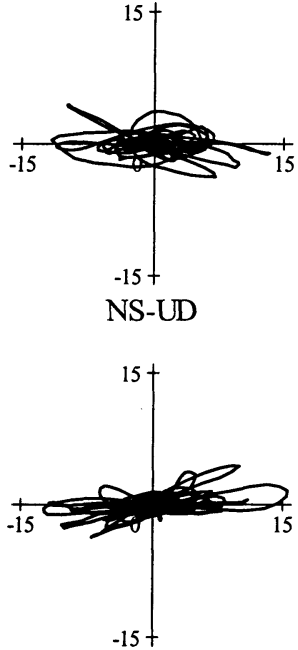

EW-UD

(b) YKS
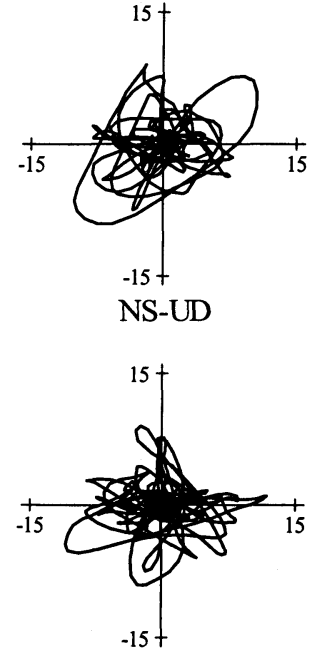

EW-UD

(c) ONR
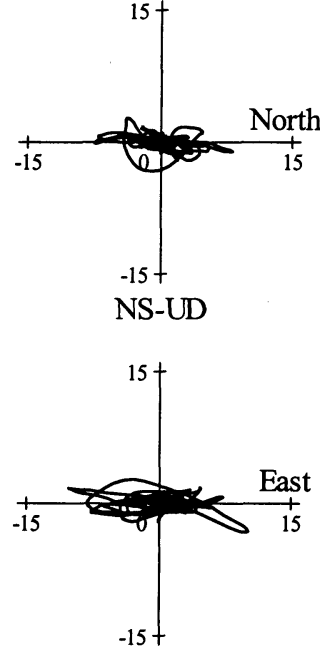

EW-UD

(d) YUI

図-7 鉛直面内での粒子加速度軌跡（3〜8 秒）

(1997/3/23, M5.0, 茨城県南部地震) 


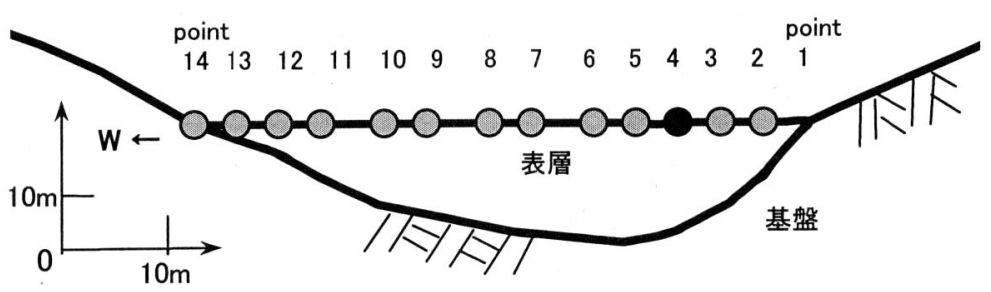

図-8 NMD 地点の地盤モデル(丸印は節点)

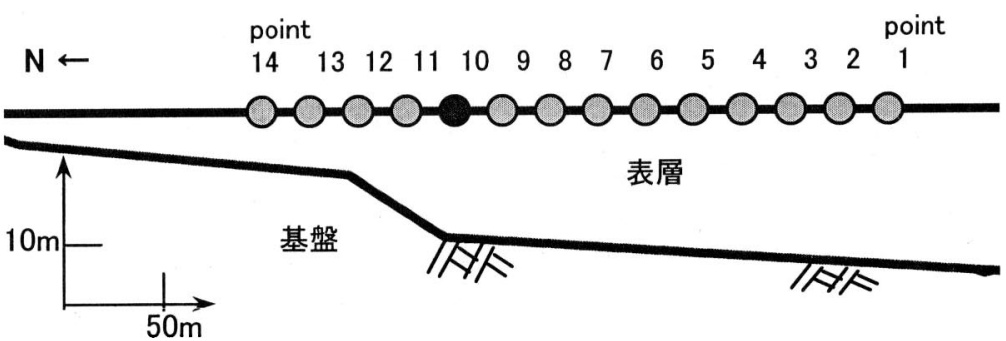

図-9ＯNR 地点の地盤モデル(丸印は節点)

表-1 解析モデルの物性値

\begin{tabular}{|c|c|c|c|c|c|c|}
\hline \multirow{2}{*}{ 測点 } & & $\begin{array}{c}\mathrm{Vs} \\
(\mathrm{m} / \mathrm{s})\end{array}$ & $\begin{array}{c}\text { 密度 } \\
\left(\mathrm{t} / \mathrm{m}^{3}\right)\end{array}$ & ポアソン比 & Q值 & $\begin{array}{c}\text { 波動インピー } \\
\text { ダンス }\left(\mathrm{t} / \mathrm{m}^{2} / \mathrm{s}\right)\end{array}$ \\
\hline \hline \multirow{2}{*}{$\mathrm{NMD}$} & 表層 & 150 & 1.7 & 0.48 & 20 & 255 \\
\cline { 2 - 7 } & 基盤 & 500 & 2.0 & 0.48 & 20 & 1000 \\
\hline \multirow{2}{*}{ ONR } & 表層 & 180 & 1.7 & 0.48 & 20 & 306 \\
\cline { 2 - 7 } & 基盤 & 600 & 2.0 & 0.48 & 20 & 1200 \\
\hline
\end{tabular}

2 参照) を平均して定めた. NMD地点ではPS 検層が 行われていないため，地質柱状図の $\mathrm{N}$ 值分布をもとに ONR地点でのN 值と S 波速度の関倸から推定して物性 值を定めた.

実際の解析では，図-8，9の太い実線上に 1.5〜5m 間 隔で境界要素を配置したが，図には一部の節点のみを丸 で示している. なお，黒丸は地震計位置にほぼ対応する.

入射波としては, 最大変位振幅 $1 \mathrm{~cm}$ をもつ $\mathrm{SV}$ 平面波 のリッカーウェーブレットを鉛直に入射した、これは, 明睹な特性周期をもつ単純な入射波を用いると，地盤の 震動状況や増幅特性を把握する上で好都合と考えたため である. 以下では，入射波の特性周期を Tip と表す.

\section{(2) 解析結果}

2 次元数值解析結果のうち, 以下ではNMD地点につ いてはEW断面, ONR地点についてはNS断面の解析結 果を示し, 観測された地震動特性との比較検討を行う.

\section{a) NMD地点}

（i）水平動と上下動の時刻歷と位相

図-10にNMD地点を対象とした解析結果の一例を示 寸. この例は, NMD地点の卓越周期に近い特性周期 (Tip=0. 3sec）をもつ入射波に対する地表の加速度波形
であり，図中の矢印 $S \rightarrow$ は地震計設置位置を示す．図-10 によれば, 水平動は各 point ごとに振幅の相違はあるも のの，周期と位相は入射波とほぼ一致している，これに 対し上下動は, point6 を境に位相が逆転している. そ して振幅は，point 4 および 10 付近で最大を示する. 地 震計設置点に近い point4 では，水平動振幅に匹敵する 上下動振幅を生じている.

(ii )加速度振幅分布

水平動の最大加速度振幅 $\mathrm{AH}$ と, 上下動の最大加速度 振幅AVの分布，および前者に対する後者の振幅比 q の 分布を図-11(a)〜(c) に示す．ただし，入射波の特性周 期 Tip は $0.1 \mathrm{sec} \leqq T i p \leqq 0.6 \mathrm{sec}$ であり，振幅分布は正 負を無視して絶対值で示している.

図-11(a)によれば水平動振幅分布は，入射波の特性周 期が 0.3 秒前後の場合，表層厚分布に類似した単峰性の 形状をしているが，周期が 0.3 秒より短周期側では峰や 谷の数が増えて高次モードの振動形に似る.また, $0.3 \mathrm{sec} よ り も$ 長周期側では，振幅分布の形は平坦にな り表層厚分布との類似性は低下寸る. 地震計設置位置に 近い point4 では, $0.15 \sim 0.30 \mathrm{sec}$ の周期成分に対して 振幅がほぼ一定なため, 共振周期が明暸でない，一方図 -11(b)によれば，上下動の振幅分布は，入射波の周期に よらず双峰性の形状をしており，その 1 つの峰の位置に point4 が対応している. そのため point4 では周期変動 に伴う振幅の増减が大きく，共振周期が比較的明瞭であ る.

さらに図-11(c)によれば，地震計設置位置における振 幅比 q は, Tip の変化に伴い $0.4 \sim 0.8$ の範用の值をと り $0.25 \mathrm{sec} \leqq T i p \leqq 0.6 \mathrm{sec}$ では, $0.6 \leqq q$ となる. 


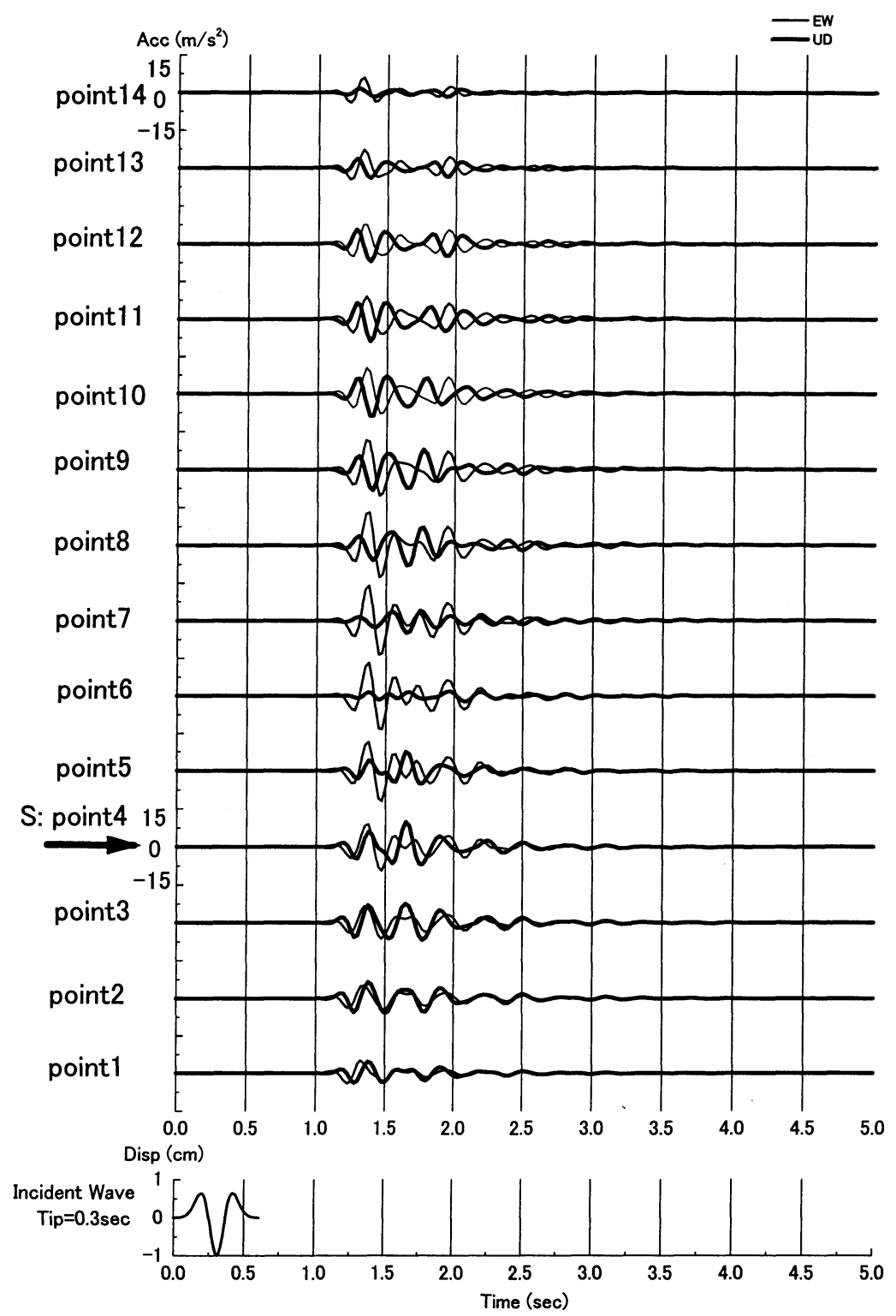

図-10 SV波入射に対する地表の応答（NMD地点）

(iii) 地震観測記録の解釈

NMD 地点周辺での振幅は Tip が $0.3 \mathrm{sec}$ 程度の入射 波に対して表層全体が一様に大きな振幅を示すことから， この周期が当表層地盤の基本振動周期にほぼ対応すると 考えられる. そこで, 周期 $0.3 \mathrm{sec}$ での地表の振動形を 図-10 から読み取って模式的に示すと，図-12 の太実線 のようになる. 同図には, 図-10 に示した point4 と 11 の時刻歴による粒子軌跡も示している. 不整形地盤の形 状や図-11(a) 及び(b)の振幅分布からも推察されるよう に,この 2 点では水平動に対して上下動は比較的大きな 振幅を示し，粒子軌跡は楕円状となることが多い.
基本周期が約 $0.3 \mathrm{sec}$ であれば， $0.25 〜 0.35 \mathrm{sec}$ の入 射波成分に対して，この表層地盤は基本振動モ一ドに近 い応答を示すことが図-11 から推察される. そのとき, 水平動と上下動の振幅や振幅比, 位相, 卓越周期などは, 上述のような特性を示すことが期待される．実際，たと えば図-6 が示すように，NMD地点では上下動の卓越 周期は $0.21 \mathrm{sec}$ にほぼ一定している一方, 水平動の卓越 周期は $0.2 〜 0.3 \mathrm{sec}$ の範囲にばらつき一定していない. また, 図-4 が示すように上下・水平加速度比は比較的 大きい. これらは当地点の地盤震動において, 図-12 に 示したような，表層地盤の振動モ一ドが支配的であるこ 


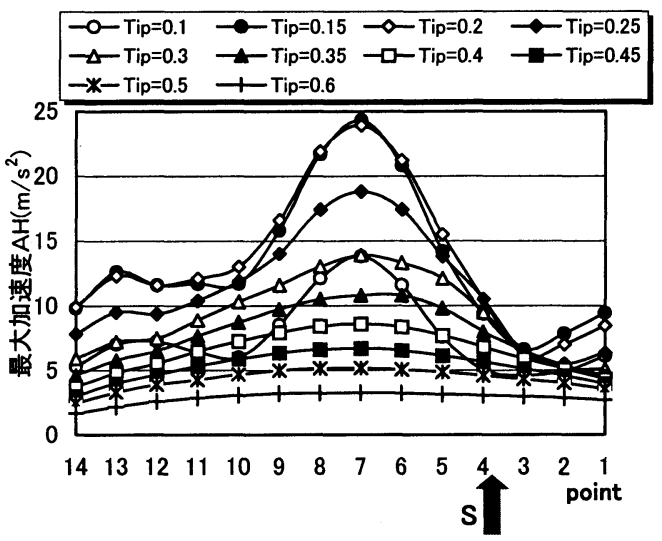

（a）水平動加速度振幅 $\mathrm{AH}$ の分布

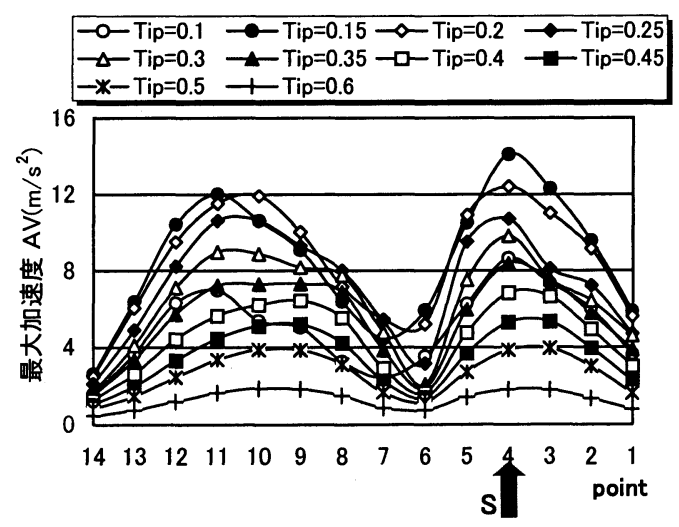

(b) 上下動加速度振幅 $\mathrm{AV}$ の分布

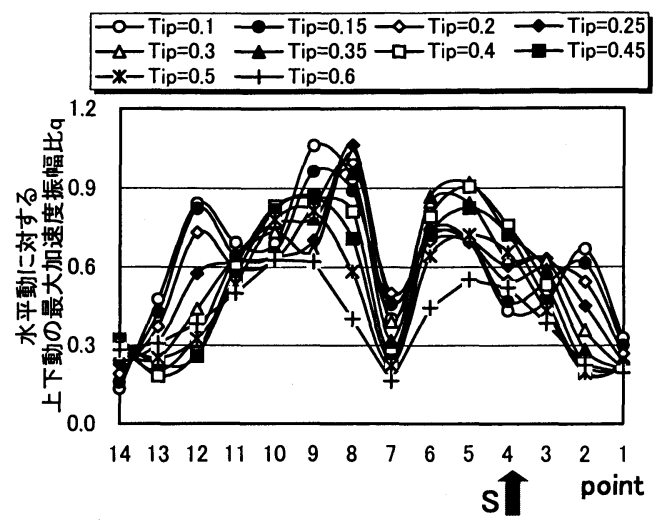

(c) 加速度振幅比 $\mathrm{q}$ の分布

図-11 変位振幅と振幅比の分布(NMD 地点)

とを示唆している.

b) ONR地点

（i）水平動と上下動の時刻歴と位相

図-13 に，ONR 地点の NS 断面に関する解析結果の 一例を示寸. これは, Tip=0.3sec の入射波に対する地表
の水平動と上下動の加速度時刻歷である. 水平動は各 point で振幅に相違はあるものの入射波の到達とともに 入射波形に類似した大きな振幅を示すが，そのとき基盤 が平坦な部分で上下動はほとんど生じていない. しかし 急傾斜基盤とその近傍(points9～12)では，比較的大き な上下動が発生し，それが北から南に向かって伝播して いる.

地震計設置地点は急傾斜基盤の終端（下端）近くであ り，この直上付近で上下動は最も大きな振幅を示す.ま た上下動が最大振幅を示す時刻の前後では, 水平動に対 して 90 度近い大きな位相差が見られる.これらの点は, 上下動が水平動と同時に発生し，しかも両者が同位相(ま たは逆位相）である NMD 地点の解析結果と対照的で ある.

(ii）加速度振幅分布

図-14(a) (c) に水平動の最大加速度振幅 $\mathrm{AH}$ と上下動 の最大加速度振幅 $\mathrm{AV}$ の分布，および前者に対する後者 の振幅比 $\mathrm{q}$ の分布をそれぞれ示す．ただし，入射波の特 性周期 Tip は $0.1 \mathrm{sec} \leqq T i p \leqq 0.6 \mathrm{sec}$ で変動させ, 加速度 振幅は図-10 と同様に絶対值で示している.

まず，水平動振幅 $\mathrm{AH}$ の分布については，周期 Tip が $0.15 \sim 0.35 \mathrm{sec}$ ではモデルの北端（図の左端）で振幅が 顕著に大きいが, 基盤急傾斜部から南一 (図中, point 12 から右へ）かけては振幅がほぼ一定している，表層の 厚さは point10から南側（図の右側）では約 $20 \mathrm{~m}$ でほぼ 一定である.この水平表層地盤の基本周期を $1 / 4$ 波長則 (T=4H/Vs) から推定すれば約 $0.4 \mathrm{sec}$ となるが，図-14 において，0.4sec よりも短周期で振幅が大きく表現さ れているのは, 前述のように入射波の変位振幅を各 Tip で一定としているためである.

上下動の加速度振幅AV の分布は図-14(b)のように, 0. $35 \mathrm{sec}$ の Tip に対し地震計設置位置 (point10) 付近 で最大となる. 空間的な振幅分布のピークは明暸でその 位置は point 10〜11 にほぼ一定している. 地震計設置位 置 (point10) での振幅変化に注目すると，0.1〜0.6sec の周期での最小振幅に対する最大振幅の比（ダイナミッ クレンジ）は，水平動は3 倍強であるのに対して，上下 動は8倍弱であり，この意味では周期の変化に伴う上下 動振幅の変化は著しいと言える.

図-14(c)によれば, 加速度振幅 $\mathrm{AV}$ と AH の比 q は, point9〜11 で最大を示す傾向がある. 地震計設置位置 においては，入射波周期 Tip の変化に伴い q $0.15 \sim$ 0.6 と変化し, Tip が $0.30 \sim 0.45 \mathrm{sec}$ のとき， qは 0.5 あるいはそれ以上となる.

なお，上下動の加速度振幅 $\mathrm{AV}$ や振幅比 $\mathrm{q}$ は，表層と 基盤との波動インピーダンス比 $\alpha$ にもかなり依存する. たとえば表-1 に示したように，図-14 は $\alpha=0.255$ に対 する結果であるが，表層と基盤のS 波速度をそれぞれ 


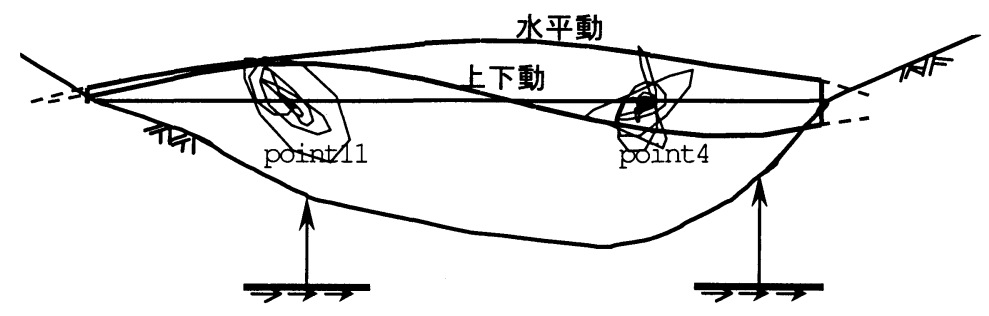

Incident SVwave

図-12 表層地盤の基本振動モード糢式図(NMD 地点)

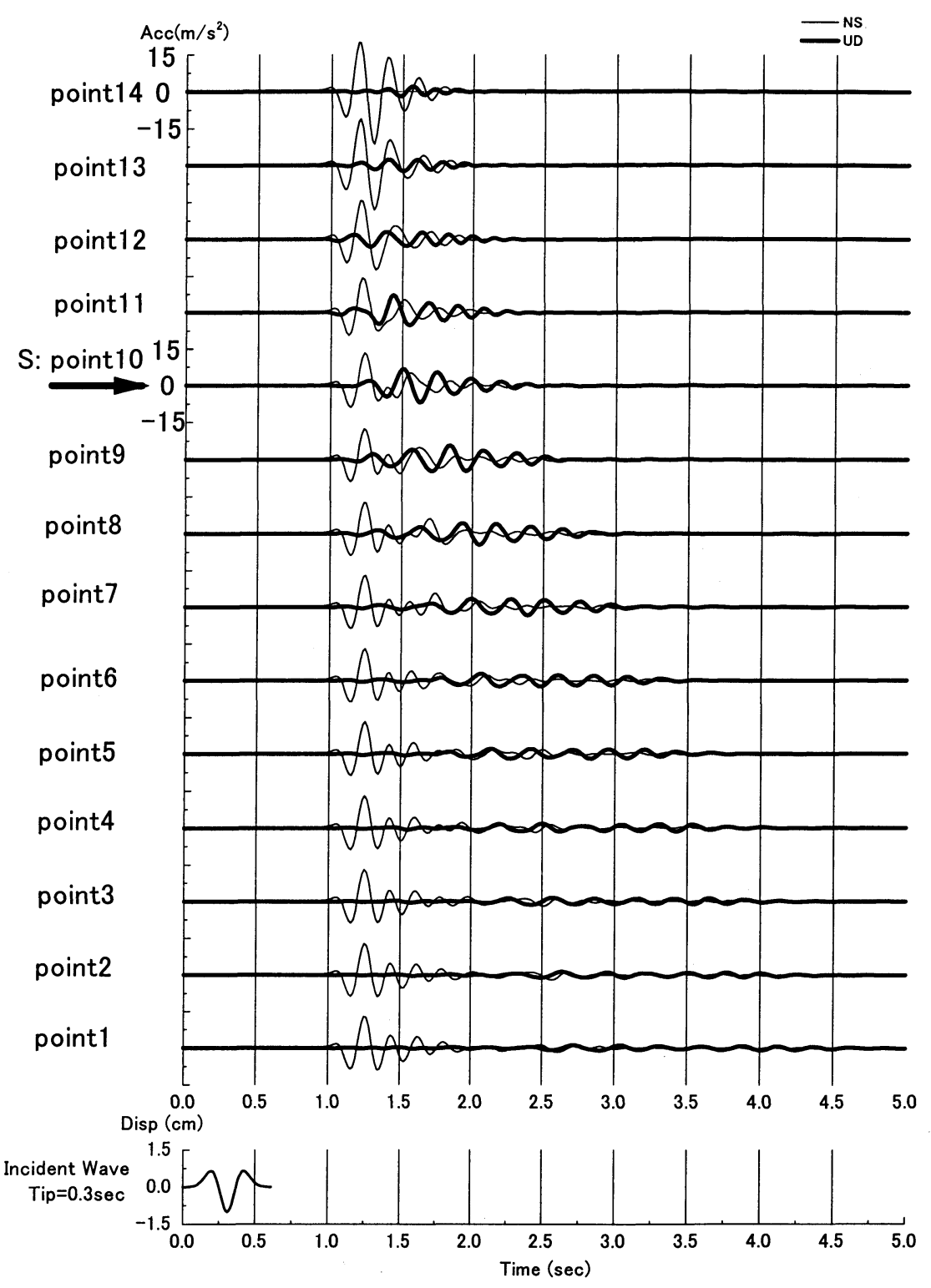

図-13 SV 波入射に対する地表の応答(ONR) 


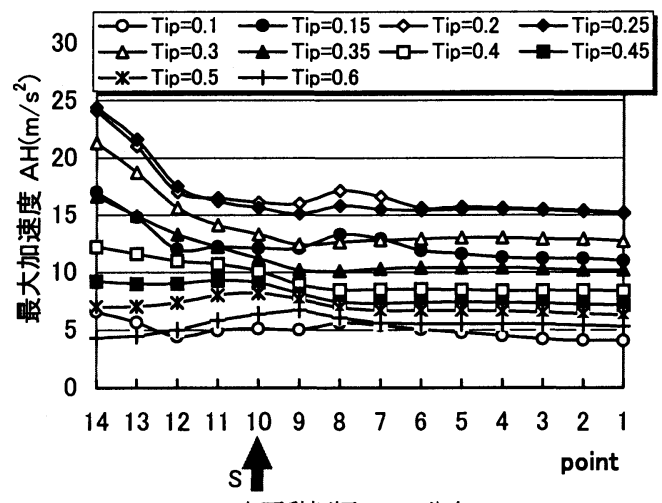

(a) 水平動振幅 $\mathrm{AH}$ の分布

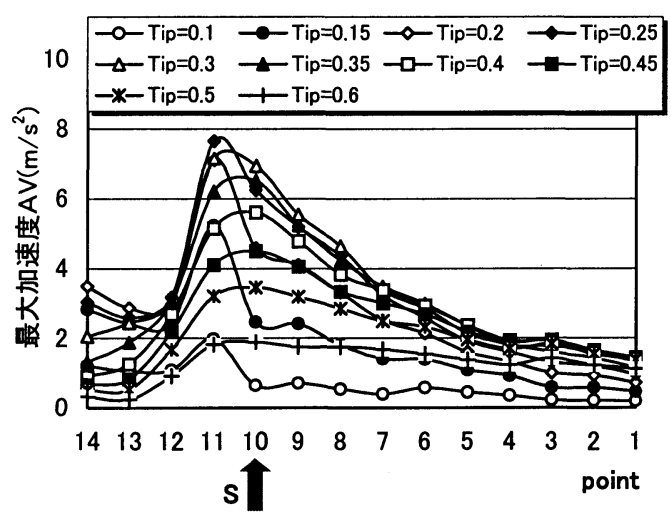

(b) 上下動振幅AV の分布

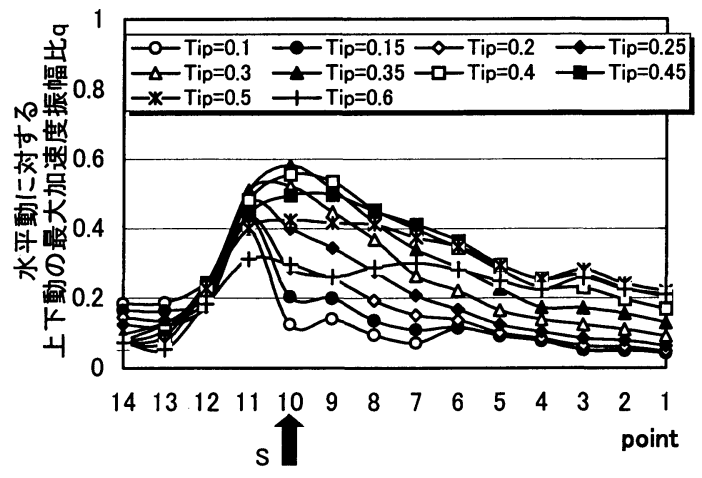

(c) 加速度振幅比 q の分布

図-14 加速度振幅と振幅比の分布(ONR 地点)

$200 \mathrm{~m} / \mathrm{s}, 400 \mathrm{~m} / \mathrm{s}$ ( $\alpha=0.425)$ とすると, このとき $\mathrm{r}$ の 最大は約 0.25 であり, 上述の最大值の $1 / 2$ 程度にしか ならない.

\section{（iii）地震観測記録の解釈}

上記の解析結果を用いて，ONR 地点の地震記録に見 られた地盤震動特性を検討してみることとする.

まず, 水平動の卓越周期が地震ごとに $0.15 \sim 0.6 \mathrm{sec}$ で変動することについては，図-14(a)の振幅分布に関連
して述べたように，基盤傾斜の影響で表層の共振周期が 明瞭でないことと関連性があると考えられる.すなわち， 入射波の周期が $0.15 \mathrm{sec}$ 程度の短周期であれば表層の薄 い北側部分が共振し，入射波の周期が長くなるにつれて 表層厚さが増す南側部分へと徐々に共振場所が移動する ため, 大きな水平動が比較的広い周期帯域で観察される ことになる. この場合, 大きな上下動は急傾斜基般部で 発生するので, 上下動の周期帯域は水平動の帯域よりも 狭いであろうと推察される. しかし観測記録で指摘され たように，上下動の卓越周期が 0.21〜0. $25 \mathrm{sec}$ の狭い帯 域におさまることは説明できない.

そこで以下では，急傾斜基盤部で発生する上下動が水 平動と 90 度近い大きな位相差をもつことや，上下動が 表層地盤を北から南一伝播することに着目し，上下動と Rayleigh 波の特性との関連性を検討してみる.

半無限弾性基盤と水平一様な表層とで成る水平 2 層弾 性地盤を考えると, その地表で Rayleigh 波基本モード は図-15に示すような粒子軌跡を描くことが知られてい る ${ }^{16)}$. すなわち, 長周期側と短周期側の極限では, い ずれも逆転の楕円形軌跡を描くが, それらの中間周期で は表層と基盤の波動インピーダンス比 $\alpha$ の違いによっ て図示の 3 のタイプに分かれる. このうちタイプ 1 は $0.5<\alpha$ の程度に $\alpha$ が大きい場合, タイプ 3 は $\alpha<0.3$ の 程度に $\alpha$ が小さい場合, タイプ 2 は $\alpha$ がこれらの中間 の場合に対応する.ここで用いた ONR 地点の地盤モデ ルは $\alpha=0.255$ であるので, タイプ 3 の粒子軌跡を描く ものと考えられる. この場合, 図示の周期 $T_{1}$ では水平 動振幅が 0 となって上下動のみとなるので, 上下動と水 平動の振幅比 $\mathrm{r}$ は, $\mathrm{r} \rightarrow \infty$ となる. また周期 $\mathrm{T}{ }_{2}$ では上 下動振幅が 0 となって水平動のみとなるので, $\mathrm{r}=0$ とな る. そして $\mathrm{T}_{1}<\mathrm{T}<\mathrm{T}_{2}$ では, 地表の粒子は順転の楕円 形軌跡を描く. さらに, 周期 $\mathrm{T}_{2}$ は水平地盤の基本振動 周期と一致し, $\mathrm{T}_{1}$ は $\mathrm{T}_{2}$ の $1 / 2$ となることも知られてい $ろ^{16)}$.

図-9 に示すONR地点の地盤モデルは水平成層地盤 ではないが, 急傾斜基盤部より南側（図の右側）の平坦 な厚い表層部分に上述の知見を適用してみる. 図-14(a) の振幅分布について既述したように，この平坦な表層地 盤の水平振動周期は $1 / 4$ 波長則から約 $0.4 \mathrm{sec}$ となるの で, これを $\mathrm{T}_{2}$ とおけば $\mathrm{T}_{1}$ は約 0.2 秒となる. また図一 13 に示した point10 の時刻歷を用いて加速度軌跡を描 くと図-16 のようになる. 同図から，上下動振幅が大き い時刻の前後では地表は順転から逆転へと移行し，大き な縦長の楕円形を描く、これらのことから, point10 付 近で現れる大きな振幅の上下動は, 主として Rayleigh 波によるものであり，それが南一伝播するにつれて正常 分散することにより，急激に振幅が減少するものと考え られる. 


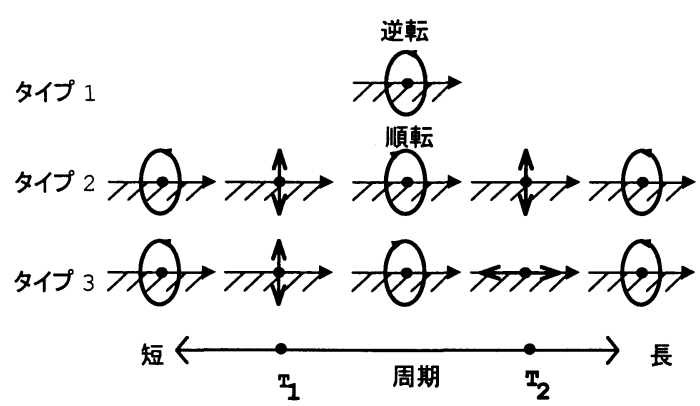

図-15 2 層地盤における Rayleigh 波基本モード の粒子軌跡 ${ }^{16)}$

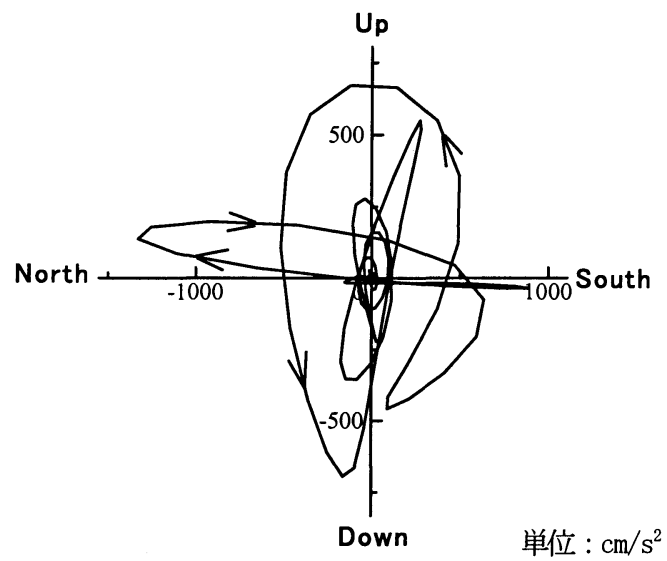

図-16 地表の加速度軌跡(ONR, point $10, T i p=0.3 \mathrm{sec})$

実測の地震記録に基づく図-6 を見ると，ONR地点 における水平動成分（EW 方向）の卓越周期で最も頻度 が高いのは $0.42 \mathrm{sec}$ 前後であり, 上下動は $0.21 \sim 0.26 \mathrm{sec}$ の範囲で卓越している. この 2 つ周期は, 上述の $\mathrm{T}_{2}$ と $\mathrm{T}_{1}$ のように，ほぼ 2:1 の関倸にある. また上下動が 大きな振幅を示すとき，地表の粒子軌跡は図-7 のよう に楕円形を描く傾向がある. これらのことからONR 地点の地震観測記録に見られる比較的大きな上下動は, 層状地盤における Rayleigh 波の特性と関連づけて考え れば大まかに説明できる.

\section{5. 結論}

鎌倉市街地での地震観測記録を分析した結果，特定の 2 地点で比較的大きな上下動が系統的に観察されること が半明した. この 2 地点の震動特性には明瞭な相違も認 められることから, 各地点で上下動が増幅される要因に ついて数值解析を用いて不整形地盤の震動特性の観点か ら検討した. 現在までに得られた知見をまとめると以下
のようになる.

1) 本研究で対象とした比較的大きな上下動は, 従来指摘 されてきたような大地震の震源近傍における地震動で はなく, 中小規模で震源距離が $50 \mathrm{~km}$ 以上の地震で観 測されたものである.

2) 西御門（NMD）地点での地震記録によれば, 上下動 と水平動の最大加速度比 $\mathrm{q}$ は平均的に 0.75 であり, 時には $\mathrm{q}>1$ となることもある. この地点では水平動と 上下動の卓越周期は，0.2 0.3sec にあり，ほぼ共通 している. また, 上下動と水平動は東西方向の鉛直断 面(EW-UD 面)内に偏向した直線状ないし楕円状の粒子 軌跡を描く傾向がある.

3) 西御門地点で観察される上記の震動特性は, 椀形基盤 をもつ表層の基本振動モードとの関連性が強いと考え られる. すなわち, 急傾斜基盤の中間部直上では, 表 層の水平変位に伴って局所的に大きな上下変位を誘発 する振動モードが励起され易く, そのためにこの地点 で上下動が増幅される可能性が高い.

4) 御成 (ONR) 地点での地震記録によれば, 上下動と水 平動の最大加速度比 $\mathrm{q}$ は平均的に 0.70 程度で, $\mathrm{NM}$ D地点よりは小さい，この地点では, 水平動の卓越周 期として $0.42 \mathrm{sec}$ が最も頻度が高いが，0.15sec から $0.60 \mathrm{sec}$ まで, 比較的広い範囲の周期成分の卓越も観 測される. 一方, 上下動の卓越周期は $0.21 \sim 0.26 \mathrm{sec}$ の狭い範用におさまっている.

5) 御成地点で上下動成分が増幅されるのは, 一端が急傾 斜基盤で他端は平坦な表層地盤が続く不整形地盤にお いて，急傾斜基盤の下端付近で上下動振幅が大きな Rayleigh 波が誘発され易いことと強く関連している と考えられる. この場合, 増幅される上下動の周期は, 平坦部表層の基本振動周期の約 $1 / 2$ である. また励起 された大きな上下動は, 平坦部を伝播する過程で分散 して急激に减衰するため, 上下動の増幅はこの場合も 局地的である.

地震観測と数值解析によって, 地震動の上下動成分が 堌幅される要因について検討した結果, 不整形地盤の震 動特性に起因する 2 種類の異なるメカニズムが考えられ ることを指摘した. 今後, 地震記録の蓄積と地盤資料な どの充実を行うことによって，本論文の内容をさらに吟 味していく必要性が高い.

謝辞 : 本研究は科学研究費補助金「都市直下地震」によ り実施した．また，鎌倉市での地震観測やBEM による数 值解析ならびに論文作成に関連し，鎌倉市や防災科学技 術研究所, 東京工業大学の関係者各位から暖かいご支援 やご助力を賜った. ここに記して, 深甚の謝意を表する. 


\section{参考文献}

1）土木学会編 : 地震動・動的物性, 動的解析と耐震設計 第 1 巻，技報堂出版，pp. 61-64，1989.

2）たとえば，日本道路協会 : 道路橋示方書・同解説 V 而震 設計編，1990。

3) Abrahamson, N. A. and Littehiser, J. J.: Attenuation of Vertical Peak Acceleration, Bull. Seis. Soc. Am., Vol.79, No.3, pp.549-580, 1989.

4) Niazi, M. and Bozorgnia, Y.: Behavior of Near-source Peak Horizontal and Vertical Ground Motions over Smart-1 Array, Taiwan, Bull. Seis. Soc. Am., Vol.81, No.3, pp.715-732, 1991.

5) Bozorgnia, Y., Niazi, M. and Campbell, K. W.: Characteristics of Free-field Vertical Ground Motion during the Northridge Earthquake, Earthquake Spectra, Vol. 11, No.4, pp.515-525, 1995.

6) Ambraseys, N. N. and Simpson, K A: Prediction of Vertical Response Spectra in Europe, Earthquake Engineering and Structural Dynamics., Vol. 21, pp.401-412, 1996.

7) Elnashai, A. S. and Papazoglou, A. J.: Procedure and Spectra for Analysis of RC structures subjected to Strong Vertical Earthquake Loads, Jour. Earthquake
Engineering, Vol. 1, No. 1, pp.121-155, 1997.

8）地盤工学会 : 地震動, ジオテクノート 9, 1999.

9) Sato, K, Kokusho, T., Matsumoto, M. and Yamada, E.: Nonlinear Seismic Response and Soil Property during Strong Motion, Special Issue of Soils and Foundations, pp.41-52, 1996.

10)たとえば, 震災フォーラム第 1 回「地震動」, 土木学会 誌,Vol. 80, pp. 37-43，1995.11. および，高田直俊：「突 き上げるような上下動」はどこへいった, 土と基礎, Vol. 44, No. 3, pp. 13-15, 1996. 3 .

11)前出 3)

12)鈴木崇伸，伯野元彦，五十嵐俊 : 地盤の不整形性による 地震動の増幅についての 3 次元シミュレーション, 阪神・ 淡路大震災に関する学術講演会論文集, pp. 103-108， 1996.

13) 土木学会 : 而震基淮等に関する第 2 次提言, 1996. 1.

14）松島義章 : 鎌倉の地質, 神奈川県立博物館調查研究報告自 然科学第 5 号, 神奈川県の地質 $1,1974$.

15)防災科学技術研究所 : Kyoshin Net CD-ROM, 1998.

16) 大町達夫, 紺野克昭, 遠藤達哉, 年綶巧: 常時微動の水平 動と上下動のスペクトル比を用いる地盤周期推定方法の改 良と適用, 土木学会論文集, No. 489/I-27, pp. 251-260, 1994. 4.

(1999. 7. 2 受付)

\title{
EFFECTS OF IRREGULAR GROUND ON VERTICAL MOTION AMPLIFICATION DURING EARTHQUAKES
}

\author{
Tatsuo OHMACHI and Kahori IIYAMA
}

For years, earthquake ground motion has been observed at 6 stations in Kamakura city, Japan. Among them, two stations of NMD and ONR have been found to show larger vertical motion. Especially at NMD, a maximum acceleration ratio between vertical and horizontal motions is sometimes exceeds 1 , with a constant predominant period of about $0.25 \mathrm{sec}$ for both vertical and horizontal motions. A 2-D BEM is applied to characterize ground motion at both stations, with a result showing that steep slopes of bed rocks under the surface layers play important but different roles for both cases. 